\title{
Regional Cumulative Effects Monitoring Framework: Gaps and Challenges for the Biobío River Basin in South Central Chile
}

\section{Marco conceptual de Monitoreo Regional de Efectos Acumulativos: Brechas y Desafíos para la Cuenca del rio Biobío en el Centro-Sur de Chile}

\author{
Gustavo Chiang ${ }^{1} 2^{*}$, Kelly R. Munkittrick ${ }^{1}$, Mark E. McMaster ${ }^{3}$, Ricardo Barra ${ }^{4}$ \& Mark Servos ${ }^{5}$ \\ ${ }^{1}$ Canadian Rivers Institute, University of New Brunswick, Saint John, NB, Canada. \\ ${ }^{2}$ Melimoyu Ecosystem Research Institute, Santiago, Chile. \\ ${ }^{3}$ Environment Canada, Burlington, ON, Canada. \\ ${ }^{4}$ Faculty of Environmental Sciences and EULA-Chile Centre, University of Concepción. \\ ${ }^{5}$ Faculty of Biology, University of Waterloo, Waterloo, ON, Canada. \\ *gchiang@centromeri.cl + 562 2953-5192
}

\begin{abstract}
Sustainable watershed management in the world is an issue that has taken much importance and attention in terms of quality and availability of water for all users in the basin. The economic growth experienced by Chile in recent years has led to increased stress on aquatic systems, especially in the Biobío river basin. The Biobío basin has faced with multiple expansions for hydroelectric power, and at the same time providing sources for competing demands from urbanization, industry, agriculture and irrigation, forestry, aquaculture, tourism, recreation, and it is a regional domain of indigenous peoples. There is a growing unease about the current process of managing single developments with Environmental Impacts Assessment (EIA). Assessing the impacts of all these threats to freshwater ecosystem is challenging. The Biobío offers an opportunity to make advances in a number of important areas for regional watershed management, including national standardization requirements for effects monitoring and for the development of a regional database. For Biobío river basin, development of such a conceptual framework requires several steps that include identifying: the scope (basin and/or subbasin) and setting (physiographic/geopolitics governance); threats to the system (past present and future); regional resource users and public services, and natural variation and gradients within the system. In these review we state what kind of pilot studies would be required to help design a Regional Cumulative Effects Monitoring Framework and must establish key design criteria including what species (species differential sensitivity) and parameters (level of organization), the magnitude of change we wish to detect and monitoring frequency are necessary to ensure sustainable management of the Biobío river basin.
\end{abstract}

Keywords: Regional Cumulative Effects Monitoring, Biobío River, biological monitoring, philosophical approach.

\section{RESUMEN}

La gestión sustentable de las cuencas hidrográficas en el mundo es problema que ha tomado una gran relevancia y atención, en términos de calidad y disponibilidad de agua para todos los usuarios de las cuencas. El crecimiento económico experimentado por Chile en los últimos años ha llevado a un aumento en el estrés a los sistemas acuáticos continentales, especialmente la cuenca del río Biobío. La cuenca del rio Biobío ha enfrentado un gran aumento en el desarrollo de hidroeléctrico, y al mismo tiempo ha tenido que proveer los recursos para demandas hídricos que compiten entre si, como son la urbanización, agricultura e riego, forestal, acuicultura, turismo, recreación, así como ser parte del territorio de los pueblos originarios. Existe una creciente inquietud sobre el proceso actual de gestión de proyectos individuales con procesos individuales de Evaluación de Impactos Ambientales (EIA). La evaluación de los impactos de todas estas amenazas a los ecosistemas dulceacuícolas es un reto no menor. El río Biobío ofrece una oportunidad para avanzar en una serie de áreas importantes para la gestión regional de cuencas, incluyendo los requisitos nacionales de normalización para la vigilancia de los efectos y para el desarrollo de una base de datos regional. Para la cuenca del río Biobío, el desarrollo de un marco conceptual como este requiere de varios pasos que incluyen la identificación de: el alcance (cuenca y / o subcuenca) y el área de gobernanza (fisiográficas / geopolítica de gobierno); las amenazas al sistema (pasado, presente y futuro); los usuarios regionales de recursos, así como los servicios públicos involucrados; la variación natural y gradientes dentro del sistema. En esta revisión planteamos los estudios piloto y criterios clave necesarios para ayudar a diseñar un 
Marco Regional de Monitoreo de Efectos Acumulativos, incluyendo la selección de especies (sensibilidad diferencial de especies), los parámetros a evaluar (nivel de organización), la magnitud del cambio que deseamos para detectar, así como la frecuencia de monitoreo necesario para garantizar la gestión sustentable de la cuenca del río Biobío.

Palabras clave: Monitoreo Regional de Efectos Acumulativos, río Biobío, monitoreo biológico, enfoque filosófico.

\section{INTRODUCTION}

Freshwater ecosystems and resources are essential to human development, and most of the human settlements have been raised near water bodies. Human use and abuse of this resource have led to alteration of complete basins, from headwaters through lakes, rivers and wetlands, increasing parallel to human economic and social development (Butchart et al. 2010). This increasing stress over freshwater ecosystem has induced a series of impacts, caused principally by water flow alteration, habitat loss, water withdrawal, urbanization, channelization, eutrophication, exotic species introduction, pollution, endocrine disruption, leading to a loss of ecosystem services and sustainability at a basin/ regional scale (Munkittrick et al. 2000; Nilsson et al. 2005; Revenga et al. 2005). These impacts occur all over the world in different rivers systems at different magnitudes for each threat, but certainly one threat never appears alone, and freshwater ecosystems are faced with multiple cumulative impacts.

Chilean rivers are not an exception. The economic development experienced by Chile in recent years has led to increased stress on aquatic systems (Fig. 1), OECD's (2013) report has shown that despite an increasing this economic and job creation phase growth (supported specially by macroeconomic policies), it has been on an environmental cost. The same organization has stated that air quality and water availability have decreased, due to the high reliance on natural resources and insufficient mechanisms to internalize environmental externalities and environmental management have been taken in place.

The Biobío river is a hotspot of freshwater biodiversity (Dyer et al. 2000; Habit et al. 2005, 2006a) and is the most impacted freshwater system in Chile, faced with an increasing urban growth (Henriquez et al. 2006; Azocar et al. 2007). It is an $8^{\text {th }}$ order river with the third largest surface $\left(24,625 \mathrm{~km}^{2}\right)$, and the second largest flow $(1,943 \mathrm{~m} 3 / \mathrm{s}$ during winter)(Parra et al. 2009).The Biobío river basin is faced with multiple expansions for hydroelectric power, and has existing competing demands from hydropower, urbanization, industry, agriculture and irrigation, forestry, aquaculture, tourism, recreation, and it is a regional domain of indigenous peoples (Parra et al. 2009) (Fig. 2).There is a growing unease about the current process of managing single developments with Environmental Impacts Assessment (EIA), and there are not well developed approaches for regional management. Assessing the impacts of all these threats to freshwater ecosystem is challenging.

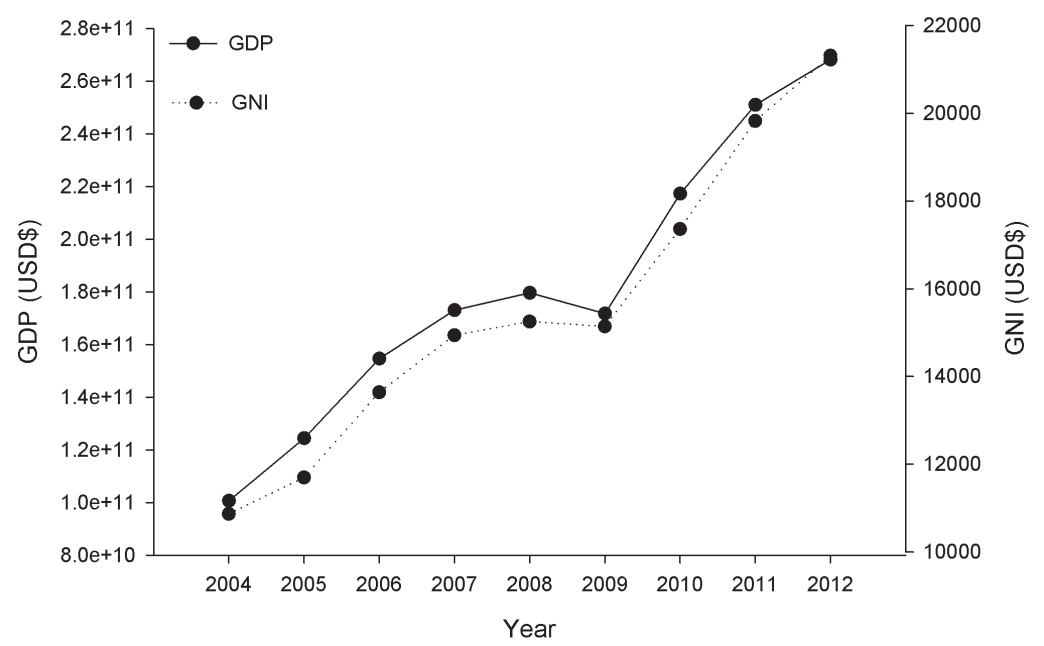

Figure 1. Economic development in Chile, years 2004-2012. Modified from World Bank national accounts data, and OECD National Accounts data files. (GDP: Gross Domestic Product; GNI: Gross National Income).

Figura. 1. Desarrollo económico de Chile entre los años 2004-2012. Modificado desde los banco de datos nacionales del Banco Mundial y OECD. (GDP: Producto doméstico bruto; GNI: Ingreso nacional bruto; ambas siglas en ingles). 

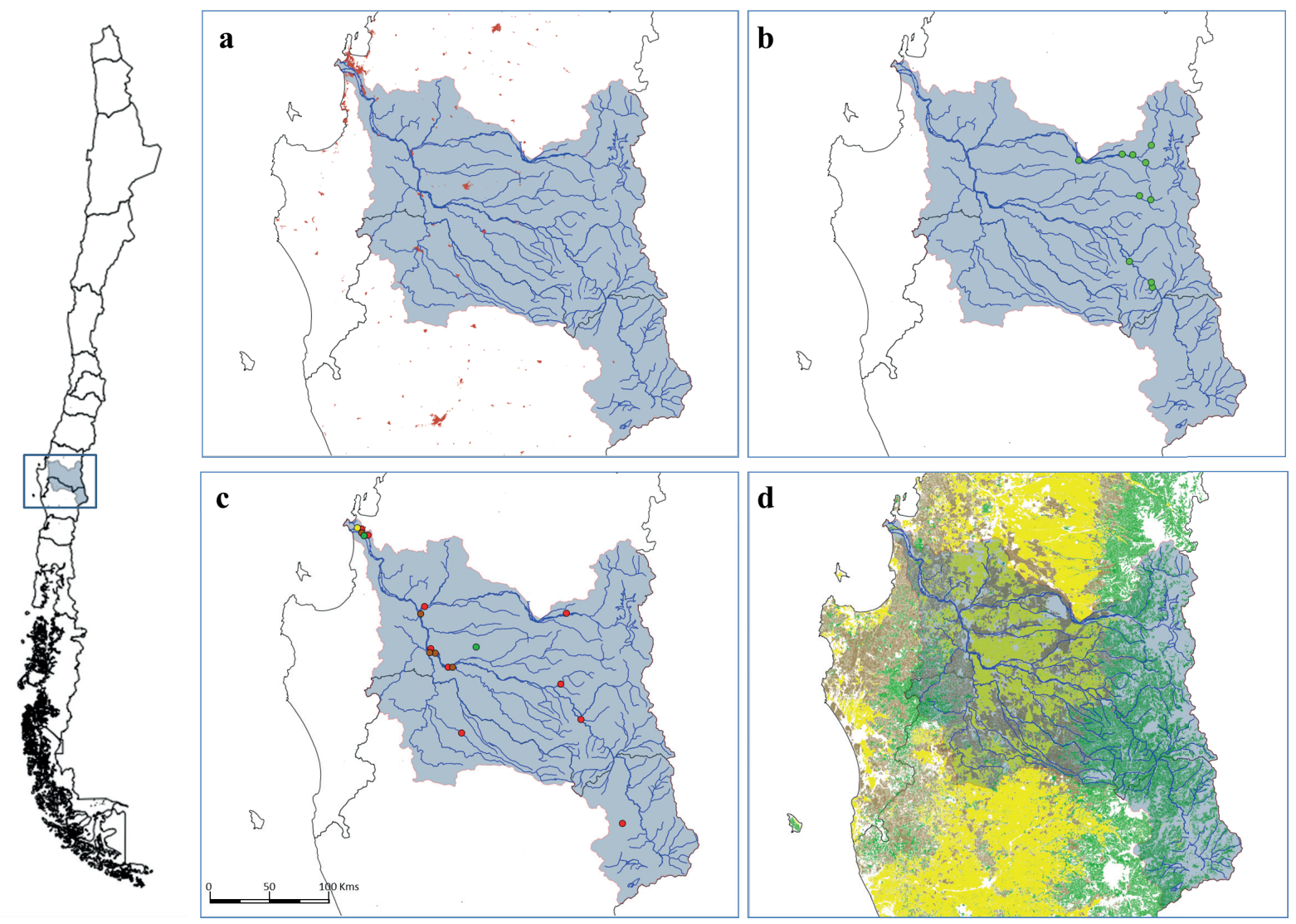

Figure 2. Multiple land uses and point source discharges in the Biobío region. A: Urban development; B: Major hydropower developments; C: Mayor point-source discharges (๑STPE; ๑PPME; Refinery; O Other industries) D: Main Landuse (๑ Forestry development; $\bullet$ Native Forest; Agriculture).

Figura 2. Múltiples usos de suelo y descargas puntuales en la región del Biobío. A: Desarrollo urbano; B: Mayores plantas hidroeléctricas; C: Descargas puntuales significativas (○PTAS; - Plantas de tratamiento de efluentes de celulosa; Refinería; ○ Otras industrias). D: Principales usos de suelo (OForestal; @Bosque nativo; Agricultura).

Cumulative environmental effects (CEE) are defined as the concurrence of increased/augmented multiple stressor impacts on a given environment (Munkittrick et al. 2000; Dubé et al. 2006, 2013). Regional Cumulative Effects Monitoring (RCEM) can be defined as holistic, dynamic, contextual and functional assessment of all those stressor responses at a regional/basin scale, assuming that actual conditions in the aquatic environment may be related to existing stressors and that new projects/land use change/ urban growth can be additive, synergistic or antagonist (Munkittrick et al. 2000), with a necessity to follow up monitoring at a region scale. Assessing those multiple impacts in freshwater ecosystems is a major challenge, and Chilean regulation has focused on Environmental Impacts Assessment (EIA), from one project to the other, in a classic strategy of classification of watersheds or reaches. Developments are ranked according to their physical and chemical composition without taking into account the cumulative impacts of the human uses over the basin/ region where the projects are settled. The United Nations Millennium Development Goals (UN MDG) include water resources objectives that include "halving the proportion of people without access to safe drinking water and sanitation by 2015" (Revenga et al. 2005) and "achieving by 2010 a significant reduction of the current rate of biodiversity loss" (Butchart et al. 2010). The Biobío river basin is the most studied basin in Chile, multiple threats to the river ecosystem that have created a decreasing water quality pattern, from headwaters to the coast (Parra et al. 2009), that along with all the physical intervention on the Biobío river, could lead it to a "strongly affected" by flow regulation and channel fragmentation classification (Nilsson et al. 2005). Accomplishing the UN's MDG will require that regional data be accessible and managed in a cohesive manner.

The existing water quality regulations in terms of environmental quality criteria are under discussion since more than 10 years, one of the limitations of such approach 
is that is based solely in physico-chemical properties and not in biological impacts. The approach proposed in this paper tries to overcome such situation, proposing a RCEM that complements the physical-chemical environmental quality criteria with biological indicators of aquatic health.

In this context, the manuscript discusses the major data gaps necessary to implement a basin/regional scale monitoring program for the Biobío river basin, the impacts on water and water resources management, along with the challenges to meet sustainability of the more impacted freshwater ecosystem in Chile.

\section{RESULTS}

ASSESSING ENVIRONMENTAL HEALTH STATUS FOR THE BIOBÍO RIVER BASIN

Assessing cumulative environmental effects at a Basin/ regional scale is a major challenge for any country, giving the large list of human activities that could have impacts of the basin (Table 1), and long term studies of water quality have increased in many rivers around the world, Chile not being an exception. Since the publication of the first Chilean Environmental Law in 1994, development and regulation has been dispersed and mostly assessed on a project to project basis. Information on the threats and impacts of human activities in different river basins has seldom been assessed on a basin scale, and has largely been focused on stressors (Parra et al. 2009). This last study has generated a large water quality data set since 1994 at a basin scale that has demonstrated a segmentation of the Biobío river basin according to human influence. The upstream headwaters reaches are still largely under natural conditions, with impacts accumulating to the river mouth, with increasing hydropower dams and channelization; small urban centres, agriculture and forestry activities; larger urban settlements and agriculture forestry activities, pulp and paper mill effluents; and finally other industrial activities. The river mouth is exposed to even larger urban discharges and a strong tidal influence (Parra et al. 2009). Despite the amount of research and study in the basin, there is a lack of a basin assessment approach and research has been focused on certain topics:

- Water diversion (intra and inter basin) and flow regulation, due to irrigation channels development, river embankment and/or hydropower.

- Water quality assessment (sewage, industrial, persistent organic pollutants).

- Aquatic ecotoxicology (mainly sewage and industrial impacts on fish and benthic macroinvertebrates).

- Land use changes and urban development impacts.
Parra et al. (2009) showed that the main factors affecting water quality are associated with anthropogenic impacts. Although water quality criteria for protecting aquatic life are met in most parts of the basin, there is evidence of a loss in native fish abundance and diversity in the same gradient (Habit et al. 2006b), where native fishes are strongly impacted downstream of industrial effluent discharges (Aedo et al. 2009). There is evidence of physiological changes in fish (Orrego et al. 2005, 2006; Chiang et al. 2011a), at low concentrations of pollutants. Along with these kinds of human activities, the change in land use and urban development has put a major threat on water bodies in the basin, with cities expanding near wetlands, lakes and rivers (Aguayo et al. 2009). This expansion in the Biobío region has been shown to be associated with exotic forest industries (Pine and Eucalyptus), and during the last 30 years, exotic plantation areas have increased over 8 fold, on areas where agriculture, prairie or native forest used to exist, displacing about 250.000 people to urban areas (Henriquez et al. 2006; Azocar et al. 2007; Aguayo et al. 2009).

This change in land use is a regional climate change force, that might have impacts on the hydrology and the changing capability of the biological systems to support human necessities, increasing the vulnerability of the ecosystems and human activities associated with the Biobío river basin. Under a near future climate change scenario, where the precipitation/snow rates decrease during winter in Biobío river basin, there will be less snow in the Andes range (Stehr et al. 2010). That implies a lower flow due to a lack of melting processes that support the second flow peak in the basin in the next spring and following summer, increasing water stress in the aquatic system. The stress on aquatic systems due to a lower flow, associated with flow changes due to hydropower dam operations could affect the quantity and quality of fish habitat for native fishes. Garcia et al. (2011) showed impacts on the availability of fish food, due to involuntary drift of macroinvertebrates. These impacts could be responsible for an observed decrease in abundance and diversity of native fishes in Biobío river basin where hydropower plants operate (Habit et al. 2007). The water stress could be responsible again for the availability of and increased exposure to certain pollutants such as PAHs in the lower part of the basin, along with some metabolic impairment observed in fish (Barra et al. 2001). All these cumulative impacts in the river could be responsible of a decrease in native fish abundance, home range and diversity in different zones along the Biobío river, especially in the middle-lower part, where multiple sewage treatment and pulp mills discharges and manipulation of the river channel occur, and an increase in exotic fish species, such as Gambusia holbrokii and Cyprinus carpio are associated with higher temperature regimes and bad water quality conditions (Habit et al. 2006b). 


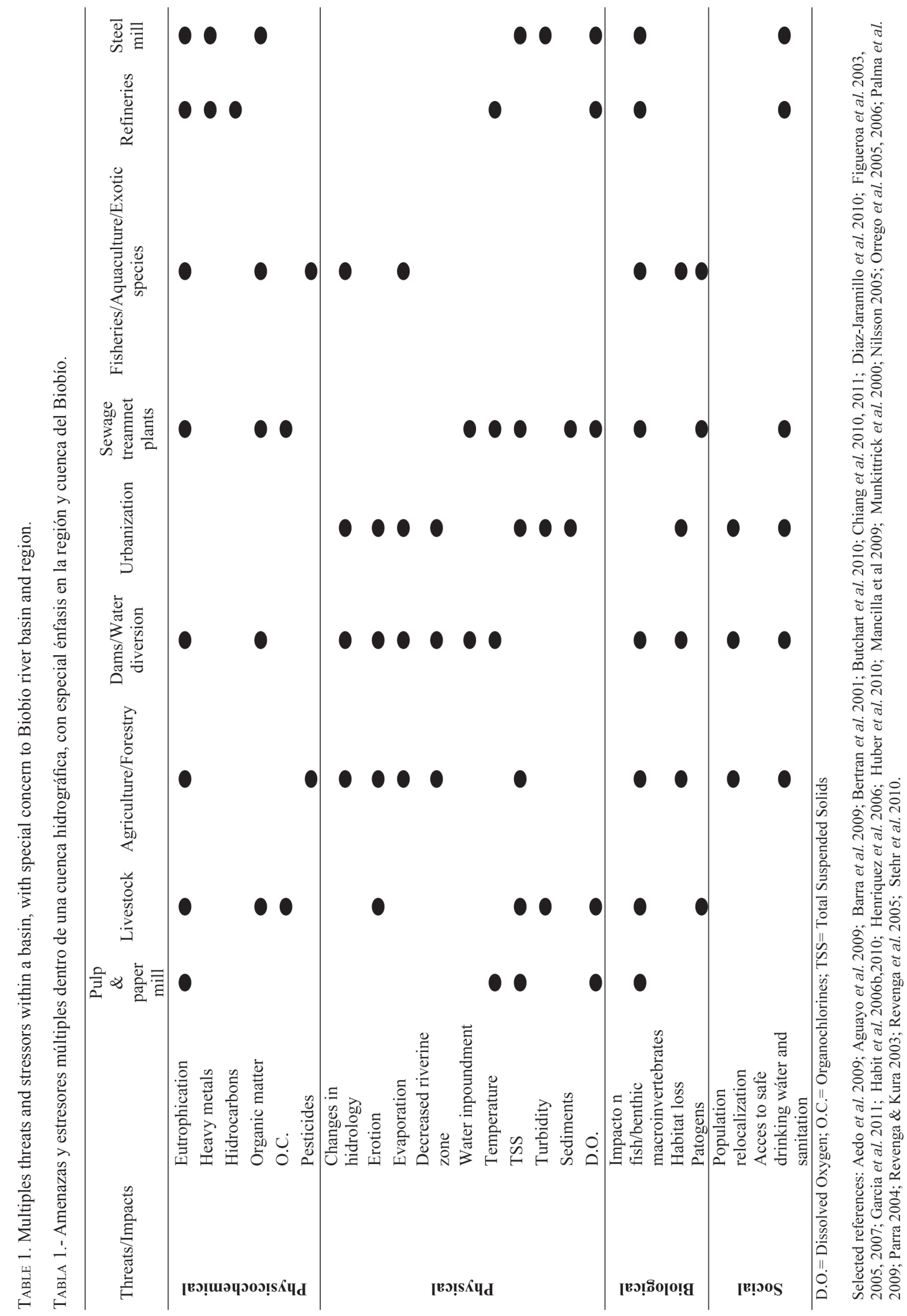


REGIONAL CUMULATIVE EFFECTS ASSESSMENT AND ENVIRONMENTAL IMPACTS ASSESSMENT

Regional Cumulative Effects Assessment (RCEA) for the Biobío basin will be a tool developed to manage the combined possible impacts of existing and future developments in the watershed. As we have argued, the proper functioning of RCEA will require detailed knowledge of the current state of the region and an assessment of cumulative effects implications of future regional human activities. However, like in other basins/regions (Johnson et al. 2011) the Environmental Impacts Assessment (EIA) system in Chile is focused on a project to project evaluation, not fulfilling the necessities of RCEA and therefore evidencing a change in the strategies to assess the combined possible impacts of existing and future activities. In addition, each project is subjected to a specific monitoring requirements, that even for similar projects are quite different in the number and type of parameters, timing and general design (number of parameters, number of sites/sampling stations type of endpoint, biological monitoring etc.).

In Chilean EIA, the primary focus of the evaluation is the robustness of the physical-chemical analysis, with methodologies commonly utilized and accepted by the engineers. The reports resulting from the various projects are unequal in data, with some EIA reports tremendously rich in data, but others needing various addenda. Unfortunately, almost all are under-utilized outside of the assessment process, as the primary objective was for gaining regulatory approval for the project. Most data are lost or inactive in the EIA System, and do not provide benefit at a regional scale. A centralized archive of environmental data currently exists with the EIA System but would need to be expanded to meet RCEA objectives. These digital centralize archive is also under-utilized and data spread across the multiple projects. As in other countries, project proponents, consultants, stakeholders and Universities involved in the sustainable development of the Region are often unaware of the existing data and/or collect very similar environmental data time and again, and most of the time with different methodologies, resulting in a waste (yet unintentional) of funds and a failure at the time to conclude if cumulative impacts occur within the basin. At the same time, EIAs are stressor-based, with predictions of effects on valued ecosystem components (VECs) predicted in "known path of action", but most of the time these stressor/VEC interaction is incorrectly known or definitely unknown (Dube et al. 2013). On the other hand RCEA monitors the accumulation of change in time and space scales with a priori and a posteriori perspectives. It is this change of state what triggers a management action for conservation and protection and works independently from uncertainties, mechanistic models and risk assessment from the EIAs that require a priori identification of stressors and cause/effect relationships (Dube et al. 2013; Squires \& Dube 2013). In the RCEA, it is the continuing monitoring and contrasting with baseline information, what would allow to track and assess the success of the predictions on how 2 or more stressors interact with the biota and if predicted future matches the current status (Munkitrick et al. 2000; Dube et al. 2013; Squires \& Dube 2013).

Regional Cumulative Effects Assessment will be important for the sustainable development and management of the Biobío basin, to assess actual and future human activities when climate change scenarios are telling us that in Chile water will flows could suffer a decrease in 40\% (Stehr et al. 2010), resulting in a decrease in quantity and quality of the resource. Assessing the impacts of all the potential threats to freshwater ecosystem using a RCEA strategy is challenging, but has greater opportunities for sustainable management of the basin: a major emphasis of the basin as an object of assessment, opportunities for the development of a regional database, and national standardization requirements for monitoring.

In an ideal RCEA framework (Fig. 3) the major threats to the watershed would be monitored using a standardized approach, a common philosophy and with consistency in timing and locations, establishing a core level of consistency for sample station selection, indicator selection, sampling frequency and timing that does not change from year to year. If a new development is approved, it only has to add monitoring sites/stations, and would already have a framework that outlined the local issues and endpoints to include, and the sites would increase the regional nature and coverage within a context, increasing the possibility to identify if the new discharge has changed the situation and trigger and prompt adaptive management (Fig. 4). The RCEA builds consistency in monitoring programs and placing sites into a regional framework, explicitly incorporating research design, scientific data analysis and effects quantification into monitoring programs, assessing and quantifying thresholds for environmental stressors, enabling the incorporation of regional data (effects-based approach) into project-specific assessments (stressorsbased approach), allowing the linkage of environmental assessment to other forms of practiced environmental management and planning (Munkittrick et al. 2000).

The focus of a RCEA for the Biobío basin is to use a set of standardized monitoring methods and sites to answer a series of questions related to cumulative impacts:

- $\quad$ Are there changes?

- $\quad$ Are the changes getting worse or better?

- $\quad$ Are the changes sustainable?

- Are they acceptable?

- What are the consequences of those changes in terms 
of future development and/or climate change different scenarios?

If we are using an effects based approach for the Biobío basin, fishes are the optimal proxies, as fish characteristics are a reflection of the energy flow through the ecosystem, reflecting factors or characteristics of the sampling sites. It is important to have indicators at the level of water quality and benthic invertebrate communities, but fishes integrate the signals and the cumulative exposures, are a level of integration of importance to stakeholders, and represent the top aquatic levels in the food web.

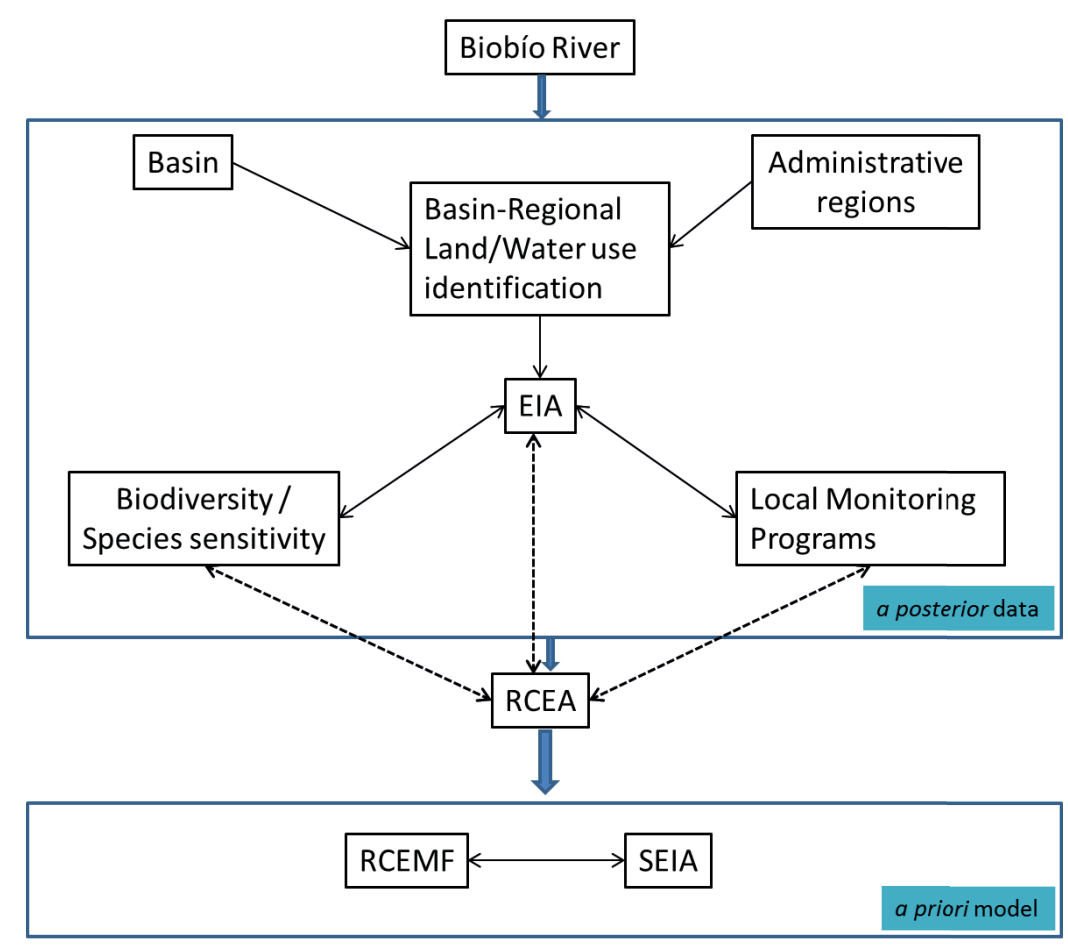

FIGURE 3. Conceptual interaction model between EIA and RCEMF for the Biobío river. EIA: Environmental Impacts Assessment; RCEA: Regional Cumulative Effects Assessment; RCEMF: Regional Cumulative Monitoring Framework; SEIA: Strategic Environmental Impacts Assessment.

Figura 3. Modelo conceptual de la interacción entre EIA y RCEMF para el río Biobío. EIA: Evaluación de Impacto Ambiental; RCEA: Evaluación Regional de Efectos Ambientales Acumulativos; RCEMF: Marco de Monitoreo Regional de Efectos Acumulativos; SEIA: Evaluación Estratégica de Impacto Ambiental.

There are three types of variability that it is necessary to understand: the variability around measurement at a site of interest, at suitable reference sites, and in the regional picture. The introduction of a stressor (chemical or physical) that produces changes outside of the natural variation of these biological responses can produce an impact in the health of the environment. So if fishes have no impacts on reproduction, growth and survival we can assume that changes in environmental conditions are not of sufficient consequence to alter the upper trophic levels. In this aspect the selection of the spatiotemporal scale of assessment is also highly relevant: changes in communitybased measures are useful to establish the ecosystem's condition and to reveal damage, however community-based monitoring is influenced by processes operating at different spatial and temporal scales, which lack the potential to establishing cause-effect relationships, and understanding the causes is crucial for potential restoration/protection of that aquatic ecosystem. On the other hand, the use of population parameters, individual responses, and tissue level effects (physiological and biochemical variables) have been demonstrated to be suitable tools that provide evidence on the effects of industrial discharges (Munkittrick 2004; Lowell et al. 2005; Sepúlveda et al. 2002; Theodorakis et al. 2006; Larsson et al. 2000; Sandström \& Neuman, 2003; Donald 2003; Karels \& Oikari, 2000; van den Heuvel et al. 2007; Orrego et al. 2005, 2006; Chiang et al. 2011a). Responses at these levels offer a warning signal of 
environmental risk for the fish fauna, providing a protective value to monitoring programs.

For a successful implementation of a RCEA in the Biobío basin, there is still a need to collect and/or fulfill data gaps in order to have a baseline scientifically strong to design a monitoring program. Regardless the endpoint measured, contaminant level or fish growth/reproduction, RCEA design should be based on the knowledge of the previous monitoring initiatives in terms of: who/when/why they used those endpoints for monitoring and how is the best way to use them. Information about variability, seasonal cycles and power analysis would help us to design a proper monitoring program, giving us information about what species is more or less appropriate as sentinel species and when/where is best to catch them (Fig. 3) (Munkittrick et al. 2009; Chiang et al. 2011b).
There exists a lot of resistance to monitor using this approach and level of biological organization, but RCEA focus is on finding differences and iteratively trying to develop an understanding, as well as it is responsibility of the researcher/ stakeholder to figure out why there exists differences between sites in a key endpoint and what it means, but as RCEA is implemented in the basin temporal and/or spatial data it could help stakeholders to establish limits of performance, which can act as triggers of concern. As RCEA is operating within the basin, functional relationships of representing the health status of the basin should be the long term objective, where outputs of the RCEA monitoring program such as temporal changes in temperature, rainfall, current velocity and others would lead to the development of a predictive relationship that could be used to monitor the performance of the a system within the basin, such as size at maturity in fishes and benthic macroinvertebrates, developmental rate in macroinvertebrates, size of young-of-the-year fishes, gonad/liver size in fish (or macroinvertebrates).
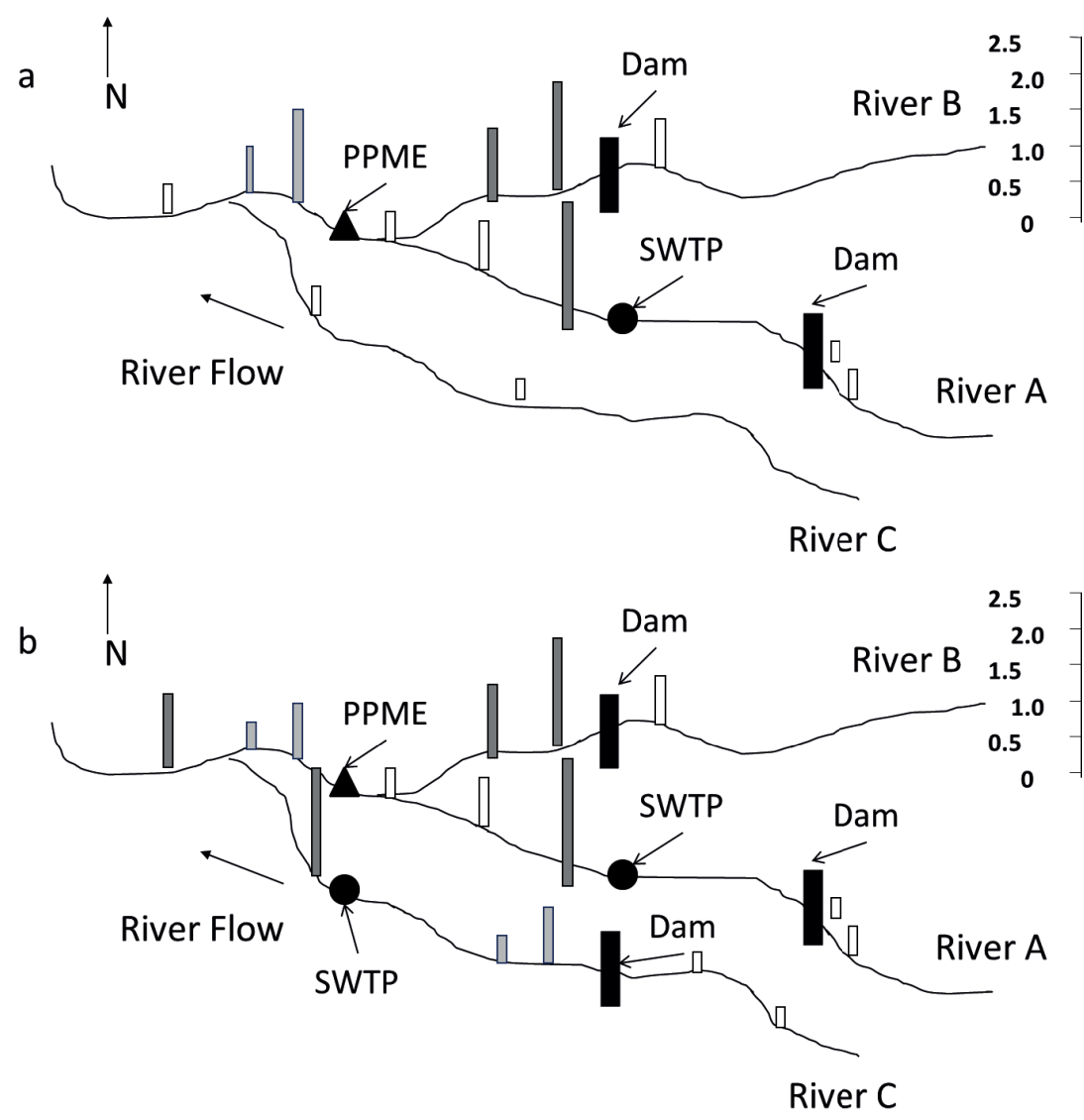

FIGURE 4. Standard Monitoring approach and spatial-temporal consistency. A: time $\mathrm{X}$ of monitoring program. B: time $\mathrm{X}+1$ of monitoring program. If a new development appears in the river reach, it just has to add monitoring sites/stations knowing the local issues and endpoints. Bars represent biological endpoint.

Figura 4. Aproximación estándar de monitoreo y consistencia espacio-temporal. A: programa de monitoreo en tiempo X. B: programa de monitoreo en tiempo $\mathrm{X}+1$. Si algún tipo de desarrollo que cambie la situación en el área del río, este solo debe sumar sumar sitios/estaciones de monitoreo, conociendo de antemano los problemas locales y los parámetros del programa de monitoreo. Las barras representan los parámetros biológicos evaluados. 
Depending on how big a change in a key endpoint that is monitored would mean that stakeholders would be concerned enough to keep monitoring or to enter assessment or investigation of cause of the observed change. Any responses that surpass a pre-established target response level will act as a warning signal, that monitoring needs to increase to develop an assessment process. Focusing on triggers to define that target response level, means the environment is protected and the situation is sustainable. CEAs have been recognized by high profile regional monitoring programs (Environment Canada 2011), and must be supported by a regional monitoring program and directed by a watershed masterplan (Dube et al. 2013) and a national water strategy (Fig. 3).

\section{CONCLUSIONS}

As we have argued, developing a RCEA for the Biobío basin and region is a major challenge, but full of opportunities. Research pilot projects should focus on the middle upper section of the river, as Parra et al. (2009) observed them to be the less impacted section of the Biobío River. Multiple reference sites along the basin and key parameters in fish and benthic macroinvertebrates that assess proper survival, growth and reproduction of individuals and populations, are integrated responses to multiple stressors and temporal/spatial variability should the assessed in order to identify sentinel species and to design statistically proven environmental effects monitoring design.

\section{ACKNOWLEDGMENTS}

The manuscript is a result of long discussions with all our colleagues during two International Workshops: Central Chile Watershed Workshop 2010, organized by EULAChile Environmental Sciences Centre, Canadian Rivers Institute and Canadian Water Network, and funded by Canadian Water Network and The Canadian Urban and Industrial discharges Environmental Effects Monitoring on Aquatic Systems: Sharing experiences with Chile, organized by Environment Canada, Canadian Rivers Institute and EULA-Chile Environmental Sciences Centre. R Barra thanks the CRHIAM CONICYT/ FONDAP Project 15130015 .

\section{BIBLIOGRAPHY}

Aedo, J.R., Belk, M.C. \& Habit, E.M. 2009. Geographic variation in age, growth and size structure of Percilia irwini from south-central Chile. Journal of Fish Biology 74: 278-284.

Aguayo, M., Pauchard, A., Azócar, G. \& Parra, O. 2009. Cambio del uso del suelo en el centro sur de Chile a fines del siglo
XX. Entendiendo la dinámica espacial y temporal del paisaje. Revista Chilena de Historia Natural 82: 361-374.

Azocar, G., Romero, H., Sanhueza, R., Vega, C., Aguayo, M. \& MuÑZ, M.D. 2007. Urbanization patterns and their impacts on social restructuring of urban space in Chilean mid-cities: The case of Los Angeles, Central Chile. Land Use Policy 24: 199-211.

Barra, R., Quiroz, R., Saez, K., Araneda, A., Urrutia, R. \& Popp, P. 2009. Sources of polycyclic aromatic hydrocarbons (PAHs) in sediments of the Biobio River in south central Chile. Environmental Chemistry Letters 7(2): 133-139.

Barra, R., Sánchez-Hernández, J.C., Orrego, R., Parra, O. \& GaVILÁN, J.F. 2001. Bioavailability of PAH in the Biobio river (Chile): MFO activity and biliary fluorescence in juvenile Oncorhynchus mykiss. Chemosphere 45: 439444.

Bertran, C., Arenas, J. \& Parra, O. 2001. Macrofauna of the lower reach and estuary of Biobio river (Chile): changes associated to seasonal changes of the river flow. Revista Chilena de Historia Natural 74(2): 331-340.

Butchart, S.H.M., Walpole, M., Collen, B., van Strien, A., Scharlemann, J.P.W., Almond, R.E.A., Baillie, J.E.M., Bomhard, B., Brown, C., Bruno, J., Carpenter, K.E., Carr, G.M., Chanson, J., Chenery, A.M., Csirke, J., Davidson, N.C., Dentener, F., Foster, M., Galli, A., Galloway, J.N., Genovesi, P., Gregory, R.D., Hockings, M., Kapos, V., Lamarque, J.F., Leverington, F., Loh, J., McGeoch, M.A., McRae, L., Minasyan, A., Hernández Morcillo, M., Oldfield, T.E.E., Pauly, D., Quader, S., Revenga, C., Sauer, J.R., Skolnik, B., Spear, D., Stanwell-Smith, D., Stuart, S.N., Symes, A., Tierney, M., Tyrrell, T.D., Vié, J.C. \& Watson, R. 2010. Global Biodiversity: Indicators of Recent Declines. Science 328: 1164-1168.

Chiang, G., Munkittrick, K.R., Orrego, R. \& Barra R. 2010. Monitoring of the Environmental effects of Pulp mill discharges in Chilean Rivers: Lessons learned and challenges. Water Quality Research Journal of Canada 45(2): 111-122.

Chiang, G., McMaster, M.E., Urrutia, R., SaAvedra, M.F., Gavilán, J.F., Tucca, F., Barra, R. \& Munkittrick K.R. 2011a. Health status of native fish (Percilia gillissi and Trichomycterus areolatus) downstream of the discharge of effluent from a tertiary-treated Elemental Chorine Free (ECF) pulp mill in Chile. Environmental Toxicology and Chemistry 30(8): 1793-1809.

Chiang, G., Saavedra, M.F., Tucca, F., Munkittrick, K.R., McMaster, M.E., Urrutia, R., Tetreault, G. \& Barra, R. 2011b. Seasonal changes in reproductive endpoints in Trichomycterus areolatus (Siluriformes: Trichomycteridae) and Percilia gillissi (Perciformes, Perciliidae), and the consequences for environmental monitoring. Studies on Neotropical Fauna and Environment 46(3):185-196.

Diaz-Jaramillo, M., Ferreira, J.L., Amado, L.L., Ventura-Lima, J., Martins, A., Retamal, M.R., Urrutia, R., Bertran, C., Barra, R. \& Monserrat, J.M. 2010. Biomonitoring of antioxidant and oxidative stress responses in Perinereis gualpensis (Polychaeta: Nereididae) in Chilean estuarine regions under different anthropogenic pressure. Ecotoxicology and Environmental Safety 73(4): 515-523.

DonaLD, R. 2003. Status and health of rainbow trout (Oncorhynchus 
mykiss) in the Tarawere River, New Zealand. In Environmental Impacts of Pulp and Paper Waste Streams. Proceedings of the 3rd international Conference on environmental fate and Effects of Pulp and Paper Mill Effluents. Rotorua, New Zealand.

Dubé, M., Johnson, B., Dunn, G., Culp, J., Cash, K., Munkittrick, K.R., Wong, I., Hedley, K., Booty, W., Lam, D., Resler, O. \& Storey, A. 2006. Development of a new approach to cumulative effects assessment: a northern river ecosystem example. Environmental Monitoring and Assessment 113: $87-115$.

Dubé M., Duinker P., Lorne G., Carver M., Servos M., McMaster M.E., Noble B., Schreier H., Jackson L., MunKittrick K.R. 2013. A framework for assessing cumulative effects in watersheds: an introduction to Canadian case studies. Integrated Environmental Assessment and Management 9(3): 363-369.

DYER, B.S. 2000. Systematic review and biogeography of the freshwater fishes of Chile. Estudios Oceanológicos 19: 77-98.

Figueroa, R., Palma, A., Ruiz, V.H. \& Niell, X. 2007. Comparative analysis of biotic indexes used to evaluate water quality in a Mediterranean river of Chile: Chillan River, VIII Region. Revista Chilena de Historia Natural 80(2): 225-242.

Figueroa, R., Ruiz, V.H., Encina-Montoya, F. \& Palma, A. 2005. Simplification in the use of macroinvertebrates in fluvial system water evaluation. Interciencia 30(12): 770-774.

Figueroa, R., Valdovinos, C., Araya, E. \& Parra, O. 2003. Benthic macroinvertebrates as indicators of water quality of southern Chile rivers. Revista Chilena de Historia Natural 76(2): 275-285.

Garcia, A., Jorde, K., Habit, E., CaAmaño, D. \& Parra, O. 2011. Downstream environmental effects of dam operations: changes in habitat quality for native fish species. River Research and Applications 27: 312-327.

Habit, E., Parra, O. \& Valdovinos, C. 2005. Ictiofauna de un sistema fluvial receptor de aguas servidas: respuestas a una nueva planta de tratamiento (río Quilque, Chile central). Gayana 69: 94-103.

Habit, E., Belk, M.C. \& Parra, O. 2007. Response of the riverine fish community to the construction and operation of a diversion hydropower plant in central Chile. Aquatic Conservation: Marine and Freshwater Ecosystem 17: 3749.

Habit, E., Dyer, B.S. \& Vila, I. 2006A. Estado de conocimiento de los peces dulceacuícolas de Chile. Gayana 70(1): 100-113.

Habit, E., Belk, M.C., Tuckfield, R.C. \& Parra, O. 2006 b. Response of the fish community to human-induced changes in the Biobío River in Chile. Freshwater Biology 51: 1-11.

Habit, E., Piedra, P., Ruzzante, D.E., Walde, S.E., Belk, M.C., Cussac, V.E., Gonzalez, J. \& Colin, N. 2010. Changes in the distribution of native fishes in response to introduced species and other anthropogenic effects. Global Ecology and Biogeography 19(5): 697-710.

Henriquez, C., Azocar, G. \& Romero, H. 2006. Monitoring and modeling the urban growth of two mid-sized Chilean cities. Habitat International 30: 945-964.

Huber, A., Iroume, A., Mohr, C. \& Frene, C. 2010. Effect of Pinus radiata and Eucalyptus globulus plantations on water resource in the Coastal Range of Biobio region, Chile. Bosque 31(3): 219-230.

Johnson, D., Lalonde, K., McEachern, M., Kenney, J., Mendoza, G., Buffin, A. \& Rich, K. 2011. Improving cumulative effects assessment in Alberta: Regional strategic assessment. Environmental Impact Assessment Review 31: 481-483.

Karels, A. \& Oikari, A. 2000. Effects of pulp and paper effluents on the reproductive and physiological status of perch (Perca fluviatilis L.) and roach (Rutilus rutilus L.) during the spawning period. Annales Zoologici Fennici 37: 65-77.

Larsson, D.G.J., Hällman, H. \& Förlin, L. 2000. More male fish embryos near a pulp mill. Environmental Toxicology and Chemistry 19: 2911-17.

Lowell, R.B., Ring, B., Pastershank, G., Walker, S., Trudel, L. \& Hedley, K. 2005. National Assessment of pulp and paper environmental effects monitoring data: Findings from Cycle 1 through 3. Burlington (ON). NWRI Scientific Assessment Report Series No. 5.

Mancilla, G., Valdovinos, C., Azocar, M., Jorquera, P. \& FIGUEROA, R. 2009. Replacement effect of riparian native vegetation on benthic macroinvertebrates community in temperate climate streams, Central Chile. Hidrobiologica 19(3): 193-203.

Munkittrick, K.R., Arens, C.J., Lowell, R.B. \& Kaminski, G.P. 2009. A review of potential methods of determining critical effect size for designing environmental monitoring programs. Environmental. Toxicology and Chemistry 28(7): 1361-1371.

Munkittrick, K.R., McMaster, M.E., Van der Kraak, G.J., Portt, C., Gibbons, W.N., Farwell, A. \& Gray, M. 2000. Development of methods for effects-driven cumulative effects assessment using fish populations: Moose River project. Published by the Society of Environmental Toxicology and Chemistry (SETAC), Pensacola, FL, USA. $256 \mathrm{pp}$.

MunKitTRick, K.R. 2004. Environmental effects of effluents from pulp and paper mills. p. 336-361. In Northcote TG, Hartman GF (ed.), Fishes and forests: an approach to fishforestry interaction. Blackwell Science, Oxford.

Nilsson, C., Reidy, C.A., Dynesius, M. \& Revenga, C. 2005. Fragmentation and Flow Regulation of the World's Large River Systems. Science 308: 405-408.

OECD. 2013. OECD's 2013 review of Chile's economy examines recent economic developments, policies and prospects. Special chapters cover innovation and entrepreneurship. DOI:10.1787/eco_surveys-chl-2013-en OECD Publishing.

Orrego, R., Moraga-Cid, G., GonzÁlez, M., Barra, R., Valenzuela, A., Burgos, A. \& Gavilán, J.F. 2005. Reproductive, physiological, and biochemical responses in juvenile female Rainbow Trout (Oncorhynchus mykiss) exposed to sediment from pulp and paper mill industrial discharge areas. Environmental Toxicology and Chemistry 24(8): 1935-1943.

Orrego, R., Burgos, A., Moraga-Cid, G., Inzunza, B., GonzÁlez, M., Valenzuela, A., Barra, R. \& Gavilán, J.F. 2006. Effects of pulp and paper mill discharges on caged Rainbow Trout (Oncorhynchus mykiss): Biomarker responses along a pollution gradient in the Biobio river, Chile. Environmental Toxicology and Chemistry 25(9): 
2280-2287.

Palma, A., Figueroa, R. \& Ruiz V.H. 2009. Assessment of a riparian and fluvial habit through QBR and IHF index. Gayana 73(1): 57-63.

Parra, O., Valdovinos, C., Habit, E. \& Figueroa, R. 2009. Long term study of the Biobío River: a complex multiuse fluvial system in Chile. Proceedings of the 7th ISE \& 8Th HIC Joint Meeting. Concepción, Chile, 2009.

Revenga, C. \& KuRA, Y. 2003. Biodiversity of Inland Water Ecosystems. Technical Series. Montreal, Secretariat of the Convention on Biological Diversity.

Revenga, C., Campbell, I., Abell, A., de Villiers, P. \& Bryer, M. 2005. Prospects for monitoring freshwater ecosystems towards the 2010 targets. Philosophical Transactions of the Royal Society B 360: 397-413.

SAndström, O. \& Neuman, E. 2003. Long-term development in a Baltic fish community exposed to bleached pulp mill effluent. Aquatic Ecology 37: 267-276.

Sepúlveda, M.S., Johnson, W.E., Higman, J., Denslow, N.D., Schoeb, T.R. \& Gross, T.S. 2002. An evaluation of biomarkers of reproductive function and potential contaminant effects in Florida largemouth bass (Micropterus salmoides florianus) sampled from the Saint Johns River. Science of the Total Environment 289(1-3): 133-1

Stehr, A., Debels, P., Arumi, J.L., Alcayaga, H. \& Romero, F. 2010. Modeling the hydrological response to climate change: experiences from two south-central Chilean watersheds. Tecnologia y Ciencias del Agua 1(4), 37-58.

Theodorakis, C.W., Lee, K.L., Adams, S.M. \& LaW, C.B. 2006. Evidence of altered gene flow, mutation rate, and genetic diversity in redbreast sunfish from a pulpmill-contaminated river. Environmental Science and Technology 40: 377-386.

Van den Heuvel, M.R., Michel, C., Stevens, M.I., Clarke, A.C., Stolting, K.N., Hicks, B.J. \& Tremblay, L.A. 2007. Monitoring the effects of pulp and paper effluent is restricted in genetically distinct populations of common bully (Gobiomorphus cotidianus). Environmental Science and Technology 41: 2602-2608.

Recibido: 10.07.14

Aceptado: 24.11.14 